(2) Open Access Full Text Article

\title{
Publishing medical schools' USMLE Step I scores: increase preclinical education accountability and national standards
}

This article was published in the following Dove Press journal:

Advances in Medical Education and Practice

13 August 2013

Number of times this article has been viewed

\section{Adam EM Eltorai}

Brown University, Warren Alpert Medical School, Providence, RI, USA

\section{Dear Editor}

Medical education innovation is a field of active investigation. ${ }^{1,2}$ Whether it is problembased learning, lectures, discussion groups, systems-based blocks, integrated courses, video-captured, pass-fail, or iPad-requiring, every medical school approaches preclinical education differently. Which combination of these methods is most effective?

To answer this, I propose that medical schools ought to be required to publish their average United States Medical Licensing Examination (USMLE) Step 1 scores annually. In doing so, the most effective education methods will emerge.

Individual school's curricular changes can function as pilot studies. For example, if one year, a medical school implements a curriculum innovation and its students perform on average 10 points higher on the USMLE Step 1, then the innovation should earn greater consideration. Or, if another medical school consistently scores below medical schools with similar student bodies, then the curricular differences should be examined.

Publishing medical schools' USMLE Step 1 scores, will increase transparency and make each school more accountable for the quality of its education. Deans of medical education around the country will be able to collaborate and implement the most effective strategies at their own schools. The "multi-institutional curricular effort"3 will progressively raise the standards of medical education, translating into better educated future physicians.

\section{References}

1. McGee JB, Kanter SL. How we develop and sustain innovation in medical education technology: keys to success. Med Teach. 2011;33(4):279-285.

2. Bland CJ, Starnaman S, Wersal L, Moorhead-Rosenberg L, Zonia S, Henry R. Curricular change in medical schools: how to succeed. Academic Medicine. 2000;75(6):575-594.

3. Thomas, P. Medical education curricula. J Gen Int Med. 1999;14:449-450.
Correspondence:Adam EM Eltorai

Brown University,

Warren Alpert Medical School,

Box G-9247, Providence, RI 02903, USA

Tel + I 4018632149

Fax + I 40I 8635096

Email aeltorai@gmail.com (c) 9 (i) 2013 Eltorai. This work is published by Dove Medical Press Ltd, and licensed under Creative Commons Attribution - Non Commercial (unported, v3.0)
BY further permission from Dove Medical Press Limited, provided the work is properly attributed. Permissions beyond the scope of the License are administered by Dove Medical Press Limited. Information on how to request permission may be found at: http://www.dovepress.com/permissions.php 
Advances in Medical Education and Practice

Dovepress

\section{Publish your work in this journal}

Advances in Medical Education and Practice is an international, peerreviewed, open access journal that aims to present and publish research on Medical Education covering medical, dental, nursing and allied healthcare professional education. The journal covers undergraduate education, postgraduate training and continuing medical education

including emerging trends and innovative models linking education, research, and healthcare services. The manuscript management system is completely online and includes a very quick and fair peer-review system. Visit http://www.dovepress.com/testimonials.php to read real quotes from published authors.

Submit your manuscript here: http://www.dovepress.com/advances-in-medical-education-and-practice-journal 